\title{
Social-Legal Environment and Women Participation in the Securities Market in Kenya
}

\author{
Nathan Mwenda Mutwiri $(\mathrm{PhD})^{1^{*}} \quad$ Caroline Jebiwott Kimutai $(\mathrm{PhD})^{2}$ \\ 1 School of business, Kenyatta University PO Box 43844-00100, Nairobi \\ ORCHID https://orcid.org/0000-0002-9158-320X \\ 2 School of business Kenyatta University PO Box 43844-00100, Nairobi \\ ORCHID https://orcid.org/0000-0001-6199-5257
}

\begin{abstract}
Securities markets are essential vehicles of raising capital, portfolio diversification and liquidity management among investors. Investors aim to generate extra returns while keeping their risk at manageable levels. Active participation of women in stock markets in Kenya is key in ensuring a level playing field for both men and women in matters development and investment. In Kenya the concentration of women investors in the Securities market has been increasing with the aim of bridging the gender gap among stockholders gradually. As at June 2020, women comprised $34 \%$ of the total investors in the Nairobi securities exchange. This reflects an increase in the number of investors to 513,063 from 273,234 in the year 2010. However, despite this increase the number of women investors was lower than male investors; women only held investment worth ksh 2.4 Billion (25\%) as compared to Ksh 7.1 billion (75\%) held by men. This clearly indicates that there is a myriad of gender related issues that prevent participation of women in stock market. This study investigated the social- legal factors that affect women participation in the stock market. The study adopted a positivist research philosophy, and a descriptive correlation design. STATA software tool was used to analyze data and the findings were presented in tables, graphs and charts. The study findings were; financial literacy levels among women in Kenya is low, some cultures in Kenya undermine women and condemn them to household chores and various family responsibilities, traditional beliefs and practices hinder women from participating in the stock market and the matrimonial property and land laws in Kenya are biased against women. The study recommends that learning institutions should incorporate financial literacy programs directed at women to help in bringing change in attitude towards participation in the securities market, younger generation of women in the society should be mentored by those who have carved out a niche for themselves in the securities market, there is need also to establish clear legal and regulatory frameworks and gender-disaggregated data gathering measures to guarantee women's secure rights to land, including the right to inherit, own, access, control, and participate in land governance.
\end{abstract}

Keywords: Securities market, social legal environment, women participation, financial literacy

DOI: $10.7176 / \mathrm{EJBM} / 13-20-14$

Publication date:October $31^{\text {st }} 2021$

\subsection{INTRODUCTION}

Stock markets play a critical role in providing alternative investment opportunities for both international and local participants in any economy (Mutwiri, 2019). Investors invest in stock markets with an aim of increasing their wealth or generate positive returns without necessarily increasing their risk to greater magnitudes (Apiyeva, 2007).Stock market participation is an important economic outcome. There is substantial welfare loss from not participating in the stock markets, since participation results to benefits from equity premium and that's an important determinant of the long-run economic welfare of an individual (Manjuala, 2013). Investment decision making is a complicated process of choosing the best available alternatives. Psychological and social factors have a bearing to investment decisions (Moueed, Hunjra, Raza, \& Asghar, 2015)

Gender equality index, indicates the degree of asymmetry between gender specific social prescriptions at the country level. The higher the rank, the lower the degree of asymmetry between men and women in that country (Barasinska \& Scafer, 2017). World Bank (2019) shows that a typical economy gives women only three fourths of the legal rights of men. However in Middle East and North Africa women have less than half of the legal rights of men. The average economy does not give women equality of opportunity. The Equality of opportunity allows women to make choices that are best for them, their families and their communities. However equality of opportunities does not exist where social legal gender differences are prevalent. The social legal biases constrain women ability to make economic decisions and have far reaching consequences. The World Bank (2021) report shows that reforms towards social legal gender equality encourage more women to work and participate in the economic decisions.

Gender investment gap is commonly misunderstood concept. A greater percentage of men invest in equities than women and this a true investment gap. Since equities outperform most other asset classes over the long run, by not actively investing in stocks the women are at a disadvantage. A Myriad of factors may have resulted to the low participation of women in stock markets. The wage gap; where the women around the world make less than 
men. In the United States and Canada women made 18\% less in 2017 when compared to men (OECD, 2021). As a result of Women making less money, they tend to have less wealth. In the United states the median US man aged 18 to 64 years had wealth of $\$ 31,150$ while the female counterpart had \$15, 120 (Stewart \& Stewart, 2019). The wealth gap has a serious gender asymmetry in the financing of stocks markets as it makes women have less resources available to invest in stock markets.

Gender equality for development is a concept that cuts across many thematic areas. Women access to economic opportunities is undermined by their lower access to production inputs, backward cultural practices and less access to information (Manjuala, 2013).Limited access to productive assets constrains women economic opportunities. An "i2i programme" by the World Bank in Rwanda which introduced targeted and precommitment savings accounts showed that women are more likely to earmark their savings to buy durable goods. A similar program in India showed that women who participated in women empowerment and rural livelihoods programmes had improved access to loans, accumulated assets and invested in education, which further made them feel more empowered (World Bank, 2021).

Social cultural constraints have limited women's access to meaningful business experience (Mbiti, Munga'tu, Mukulu, \& Kyalo, 2017) and access to finance. Family obligations interrupt women progression in career and business and this negatively affect their ability to accumulate their capital therefore limiting their involvement in stock markets. Socialization patterns and gender division of labour have a bearing on the participation of women in stock markets. The socialization pattern prepares young boys for the world of productive work and decision making. While on the other and girls are trained to be effective housewives and mothers. This instils at very early age in a girls mind that their major purpose is taking care of their household responsibilities (Tuladhar \& Finnegan, 1996)

The East African laws affect the ability of women to access finance and participate in stock markets. Both public as well as private laws have an influence on women. Laws regarding land ownership, divorce, inheritance seem to favor men as opposed to women. For instance in Kenya, as much as the constitution provides for equal rights between men and women before, during and after marriage, the need to show evidence of financial contribution for women seems to disadvantage them because mostly women contribution is in form of household chores and taking of the family. This affects women negatively in their ability to accumulate assets which would enable them to meaningfully participate in stock markets.

\subsection{Problem Statement}

Stock markets are critical for any economy, they provide investment avenues as well as liquidity management for investors. Despite the importance of capital markets as a vehicle for economic development, women investors' participation in Kenya is below that of their male investors. This is because women face a myriad of challenges which hinder them from catching up with their male counterparts. The social construction in most East African countries, undermines women contributions in matters investment and development. Traditional norms dictate that women should not inherit or own land and this limits them in accessing financing. The legal framework in East Africa countries relating to inheritance, divorce and matrimonial property seemingly favor the male gender. The legal framework, social construction compounds the gender financing asymmetry which is skewed towards to men and these factors have an influence on the level of participation of women in the stock markets.

In Kenya the concentration of women investors in the Nairobi Securities Exchange has been increasing with the hopes of bridging the gender gap among stockholders gradually (Kinuthia, 2020). As at June 2020, women comprised $34 \%$ of the total investors in The Nairobi securities exchange. This was an increase in number of investors to 513,063 from 273,234 in the year 2010. However despite this increase the number of women investors, women only held ksh 2.4Billion shares as compared to Ksh 7.1 billion held by men (CMA, 2020). This means there is a long way before we achieve the gender parity in stock market participation in terms of volume and value. There is scanty literature on the social and legal framework and their effect women participation in stock markets. This study seeks to fill these gaps, by establishing the social, legal factors that influence women participation in the stock markets in Kenya.

\subsection{Specific Objectives}

The study seeks to achieve the following objectives

(i) To establish the social-cultural factors that hinder equal participation of women in the Securities markets in Kenya

(ii) To establish the legal environment in Kenya that affects the women participation in securities markets

\subsection{LITERATURE REVIEW}

Myers (1984) pecking order theory states that investors have several sources of capital to choose from and they have preferences based on the cost and risk associated with each source. Therefore lack equal access to stock markets by women caused by social, legal and gender biases has an effect on level of women participation in stock 
exchanges in Kenya therefore disadvantaging women economically.

Margaret and Peggy (1970) Marxist feminism theory, analyzes ways in which women are exploited through capitalism and individual ownership of private property. The proponents of this theory postulate that complete women liberation can only be achieved through dismantling capitalism systems which favor men.

Mohammadi and Shafi, (2017) reported that gender related differences on investment behavior are due to risk preferences between men and women. The study found that women are more risk averse in equity investments. The study found that female investors are less likely to invest in securities markets. Barber and Odean (2001) opined that overconfidence investors trade excessively. The paper tested overconfidence between men and women. The study further developed models that showed that overconfident investors overstimate the precision of their knowledge about the value of financial securities.Men are generally more overconfident tha women.Therefore this study will seek to establish if the women particpaition in stock markets is affected by social and cultural afctors than make them less confidence.

Behavioral finance shows that individuals do not always behave rationally due to behavioral biases. Willows and West (2015) found that men is Southafrica are more overconfidennt while their women counterpart riky averse. In addition, trading frequency of men is statistically signicantly higher tha women.

Gender is a social construct that infleuence the decisions of womenl through out the life. Women are not isolated entirely in their social setting as they make investment decisions. This is because as members of society, people are either consciously or unconsiouly influenced by social actors whom they come across in their daily lives (Manjuala, 2013).

\subsection{RESEARCH METHODOLOGY}

This study will use a descriptive research design and adopt a positivist research philosophy. Aliyu, Bello, Kassim, and Martin (2014) contends that positivism philosophy is adopted when using observable social reality and because of the structured nature of the research and scientic approach, the results are independent of the researchers views and are widely generalizable. The target population was the women investors in the Nairobi Securities Exchange. The research will collect primary as well as secondary data from Nairobi securities Exchange. Data was analyzed using excel spreadsheet for cleaning and coding. The findings were presented in graphs, tables and charts.

\subsection{FINDINGS}

\subsection{The Composition of male and female investors at NSE}

The study found that as at March 2021 the male investors were 1,036,413 (66\%) while the female investors were 533,093 (34\%). This indicates that women have a lower participation at NSE compared to the male investors therefore there is need to come up with efforts to increase the women participation in the stock market in Kenya. The number of shares held by male investors was $8,152,541,812$ while the number of shares held by women is $2,566,384,593$. This indicates that male investors held three times the number of shares held by women.

\subsubsection{Number of investors at NSE}

Figure 4.1 indicates the male investors are more than half of the total numbers of investors at NSE. This shows a big gender disparity for a country which aims to elevate women to equal status with their male counterparts in all spheres including economic participation. The gap can be attributed to various factors such as social, cultural, and legal factors that limit women from participation in the stock market.

\section{Number of investors at NSE as at March 2021}

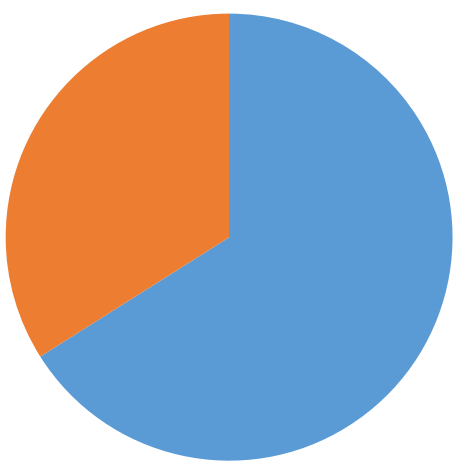

Figure 4.2 Gender composition of Investors at NSE 


\subsubsection{Gender Holdings of shares at NSE}

Figure 4.2 indicates that the number of shares held by Male investors is three times the number held by women investors. This can be attributed to several factors. Firstly, Women are risk averse compared to Men, therefore they invest sparingly in the securities markets. Secondly, there exists an income level disparity which disadvantages women. Most women do informal family support duties such as taking care of children and supporting men psychologically as they engage in formal income generating activities. This disadvantages women because they have less disposable income as compared to men and therefore lack funds to invest in securities markets.

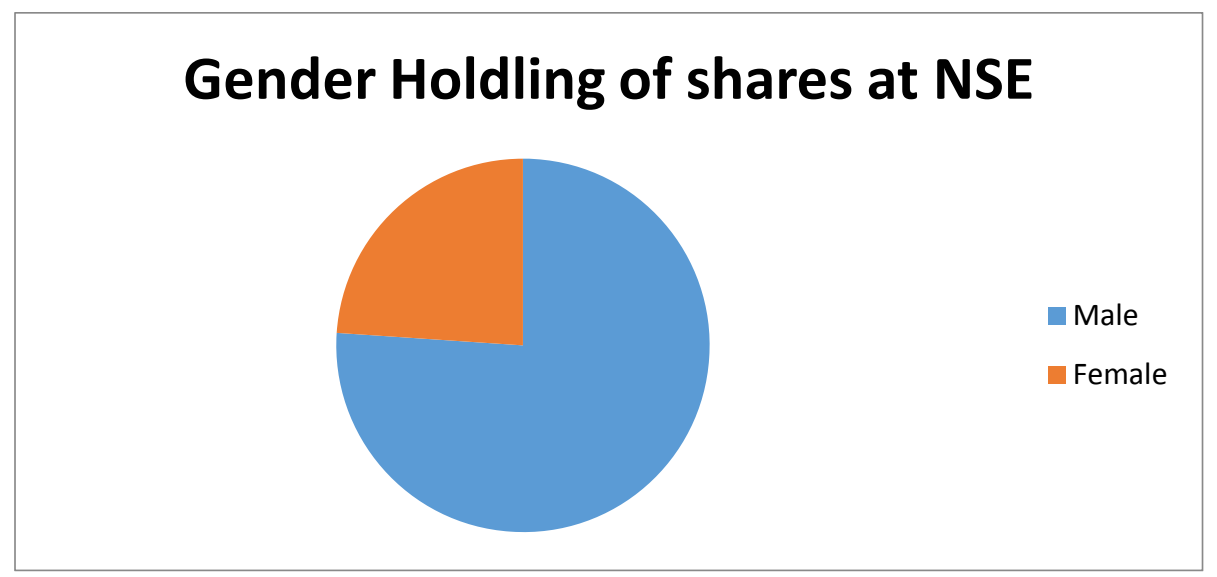

Figure 4.2: Gender holding of shares at the Nairobi securities exchange

\subsection{Social-Cultural factors}

The study found that in the society there are some cultural practices such as early marriages, wife inheritance female genital mutilation among others which belittles women. These practices makes men subjugates women making them have a low self-esteem hindering them from participating in the securities market as they perceive matters investments are male dominated. Further, the politicians and those in leadership play a key role in ensuring that these practices are not eradicated for their political gains. There is dire need to reorient the retrogressive cultural traditional believes and practices so as to enable women participate in the securities market

The study found that the literacy level of women is lower than the literacy level of men in Kenya because of the social cultural practices. Financial literacy is linked to financial decisions. Women who are financially literate are more likely to invest in the securities market this is because the financial literate women are able to take risks and are more confident. Confidence and financial literacy is key to financial decision making and participation in the securities market. Further, the study found that women generally show lesser financial knowledge have more financial concerns and are less confident about their financial situations because of their traditional gender roles.

The study found that social interactions are a key factor that affects women participation in the securities market. The participation in the securities market can be influenced by the way the women socialize with their peers and through various networks this is because socializing with peers (herding behavior) is likely to influence the financial decision making. Different ways of social interactions has different impacts on securities market participation therefore, by women interacting with different people the effects are not the same hence a need to diversify the social interactions. In behavioral finance the herding behavior influences the investment decisions. Through social interactions women can access information regarding investment in the securities market. In addition, social interactions not only influence participation by women but it also makes them active participants through trading frequently in the market.

\subsection{Legal Framework}

Legal environment affect many spheres of life including investments. Investment decisions are based not only on information access and available alternatives but also ability to raise capital to invest in alternatives. Therefore legal factors that hinder the ability of women to own assets which can generate incomes or can be used as collateral undermines their potential to match the scale of their male counterparts in securities markets.

The Kenyan constitution of 2010 provides in Article 43(3) "Parties to a marriage are entitled to equal rights at the time of the marriage, during the marriage and at the dissolution of the marriage." Providing a level playing environments but also provides for alternative dispute resolution mechanisms which include reconciliation and traditional dispute resolution mechanism. These tradition mechanism have mainly favored men as opposed to women because of the patriarchal systems that exist in most traditional cultures. Therefore any disputes involving land or inheritance are solved by elders and because of the subjugation of women position in the traditional society 
the women end of getting lesser share in terms of any property disputes.

The customary laws which are applied by elders to solve property disputes, mostly discriminate against land ownership by women. These customary laws control more than $65 \%$ of the land in Kenya according to human rights watch. This explains why only $10.3 \%$ of Kenyan women own land title deeds. These backward customary laws which do not give women an equal chance to own important property such as land prevents women from accumulating assets and income since land is production factor and deny them an equal chance to invest in securities markets in Kenya.

The Matrimonial property Act 2012 though packaged as statute to ensure equality in parties to marriage, it has led to widening the gap between women and men in regard to ability to accumulate wealth. Section 7 of Matrimonial property Act 2013 provides that ownership of matrimonial property vest in the spouses according to the contribution of either spouse towards its acquisition and shall be divided between the spouses in case of dissolution or divorce. This position has been stated in many Kenyan matrimonial causes such as AKM v NNN [2019] eKLR by Judeg R.K Limo and M A A v A R [2018] eKLR by Judge S.J Chitembwe. This disadvantages women because they are unable to prove their contribution towards acquisition of matrimonial property and therefore they are unable to accumulate assets and savings which would have enabled them participate in securities markets.

The Law of succession Act 2012 in section 32 and 33 excludes the application of the statutes to districts (ie West Pokot, Turkana, Marsabit, Mandera, Wajir, Garissa, Tana river, Narok, Samburu, Isiolo, Lamu and kajiado) in respect of intestate death on agricultural land, crops and livestock. The Act stipulate in section 33 that the customs and culture should be applicable while determining the distribution of the deceased estates. This condemns women to unfair discrimination because these customs are biased to the favor of men and women are seen only to play house chores and therefore they end up being disinherited and thus denies them the financial capacity freedom to invest in securities markets. The Act also openly discriminates against women by providing in Section 35(5) that the residue of the net intestate estate shall devolve upon the surviving child or children in case a widow remarries. This provision does not apply to widower. Therefore the law robs widows who opt to remarry their right of inheritance in case of intestate death and this also reduces their ability to invest in securities markets.

\subsection{RECOMMENDATIONS}

The social norms and practices account for the inequalities between men and women. In most societies in Kenya capabilities and activities conventionally associated with women are allocated lower value. There is need for the society to eradicate the stereotypes relating to women that prevail in Kenya. This will change the current patriarchal society which elevates men at the expenses of women. Backward practices such as wife inheritance, early child marriages, female genital mutilation which degrade women and rob them the financial independence should be eradicated. This will empower women and give them a stronger footing to participate in securities markets.

The education system in Kenya should introduce education programmes on financial literacy directed at women with the aim of bringing about a change in the attitudes, beliefs and behavior of women who are less confident when it comes to investing. These programmes should aim at making women aware of the financial instruments traded at the securities market and the entire process of investing in the market hence enabling women change their investment attitude and behavior which in turn increases their participation in the securities market.

The Marriage Acts which calls for registering of all marriages which effectively grants women the legal basis for land ownership. Whereas the Act requires all marriages to be registered including traditional marriages, more public awareness on the requirement of registration of forms of marriages is essential to ensure that most of traditional marriages are registered. This will elevate women from just accessing and using the land to actually controlling it and this will give them collateral required to access loans and generate more disposable incomes so that they are able to participate more in securities markets.

The Marriage Act also seemingly elevates the civil marriages and western culture of monogamy as opposed to the many Kenyan cultures which practice polygamy. The Acts invalidates polygamy setups in cases where the first marriage was civil as it postulates such men have no capacity therefore such unions are not recognized in matrimonial causes. This position does not speak to the realities in most communities where cohabitations and polygamy is practiced. This act therefore denies women who have been in long cohabitation with men a chance to benefit from property in case of disputes even when the women have played a key role in acquisition of such assets. This limits the participation of women in investments activities including securities markets.

There is need to amend the Law of succession Act Section 32 and 33 so as to ensure that it applies to all communities in case on intestate deaths. In its current forms it condems women in West Pokot, Turkana, Marsabit, Mandera, Wajir, Garissa, Tana River, Narok, Samburu, Isiolo, Lamu and Kajiado to discriminatory traditional cultures that disinherit women robbing them their rights to fully benefit from the deceased spouse and hence weakens their economic status. An amendment would enable women in these areas benefit economically and strengthen their asset bases enabling them to participate in economic activities and investments including securities Markets. 


\section{References}

Aliyu, A., Bello, M., Kassim, R., \& Martin, D. (2014). Positivist and Non-Positivist paradigm in social science Research. Journal of Management and Sustainability, 4(3), 79-95.

Apiyeva, D. (2007). The determinanats of securities markets performamce in emerging economies; the case of latin American and Asia Pacific. Middlesex University Reserach Repository.

Barasinska, N., \& Scafer, D. (2017). Gender Role Asymetry and Securities Market Participation-Evidence from four European Household Surveys. The European Journal of Finance, 1-26. doi:https://doi.org/10.1080/1351847X.2017.1371622

Barber, B. M., \& Odean, T. (2001). Boys will be boys:Gender, Overconfidence and Common Securities Investment. Quartely Journal of economics, 116(1), 261-292.

Dirk, S., Andreas, F., Maximilian, G., \& Wolfgang, B. (2018). Public corporations in Africa A continental survey on securities exchanges and capital markets performance. Jena Economic Research Papers,Sciller University.

Idris, I. (2018). Barriers to women's economic Inclusion in tanzania. Birmingham: GSDRC, University of Birmingham. Retrieved April 7th, 20121

Kinuthia, K. (2020). Women investors' clout rises at the NSE. Business Daily. Retrieved March 30, 2021, from https://www.businessdailyafrica.com/bd/data-hub/women-investors-clout-rises-at-the-nse2301098\#: :text=Summary,percent $\% 20$ of $\% 20$ the $\% 20$ total $\% 20$ investors.\&text $=$ There $\% 20$ were $\% 201 \% 2 \mathrm{C} 0$ 00\%2C955\%20registered $\% 20$ male $\% 20$ investors $\% 20$ on $\% 20$ the $\% 20$ NSE $\% 20$ as $\% 20$ at $\% 20 J u n e$.

Manjuala, V. (2013). Social dynamics of Gender and risk in securities Market. International Journal of Humanities and Social Science Invention, 2(4), pp.36-41.

Mbiti, F. M., Munga'tu, J., Mukulu, E., \& Kyalo, D. (2017). The Influence of Social- Cultural Factors on Growth of women- Owned Micro and Small Enterprises in Kitui County, Kenya. Journal of Busimess and Social science, 6(7). Retrieved from http://ijbssnet.com/journals/Vol_6_No_7_July_2015/25.pdf

Mohammadi, A., \& Shafi, K. (2017). Gender differences in the contribution patterns of equity-crowdfunding investors. Small Bus Econ, 50, 275-287. doi:DOI 10.1007/s11187-016-9825-7

Moueed, A., Hunjra, A. I., Raza, B., \& Asghar, M. U. (2015). Role of psychological and social factors on investment decision of individual investors in islamabad securities market. National College of Business Administration \& Economics.

Mutwiri, N. M. (2019). Systematic Risks and Performance of securities exchange in Kenya. PHD Thesis, Kenyatta University.

Myers, S. C. (1984). The Capital structure Puzzle. The Jornal of Finance, 39(3), 574-592.

Odean, T. (1998). "Volume, Volatility, Price, and ProŽt When All Traders Are. Journal of Finance, 1887-1934.

OECD. (2014). United Republic of Tanzania. OECD;Social Institutions\& fGender Index. Retrieved from https://www.genderindex.org/wp-content/uploads/files/datasheets/TZ.pdf

OECD. (2021). Gender Wage Gap. doi:OECD (2021), Gender wage gap (indicator). doi: 10.1787/7cee77aa-en (Accessed on 09 April 2021)

Powell, M., \& Ansic, D. (1997). Gender diffrences in risk behavior in financial decision making; An experimental analysis. Journal of Economics Psychology, 606-628.

Saunders, M., Lewis, P., \& Thornhill, A. (2009). Reserach methods for Business students. England: Pitman Publishing imprint.

Srijanani, D. T. (2018). A Study on Impact of gender in Investment decisions. doi:DOI: 10.18231/23942770.2018 .0025

Stewart, B., \& Stewart, D. (2019). The Equality Equation: Three Reasons Why the Gender investing Gap is closing. Enterprising Investor;Pratcical analysis for Investment professionals. CFA Institute. Retrieved April 9th, 2021, from https://blogs.cfainstitute.org/investor/2019/05/22/

Tuladhar, J., \& Finnegan, G. (1996). Factors Affecting women Entrepreneurship in Small and Cottage Indusries in Nepal:Opportunities and Constraints. International Labour Orgarnization South Asia Multidiscplinary Advisory Team \& Swedish Internatinal Development Cooperation Agency.

Willows, G., \& West, D. (2015). Differential Investment performance in south africa. International Business \&economics Reasearch Journal(IEBR), 14(3), 537.

World Bank. (2019). Women, Business and The law; A decade of Reforms. World bank Group.

World Bank. (n.d.). Gender Equality for Development. Development Imapct Evaluation(DIME). Retrieved April 9th, 2021, from https://www.worldbank.org/en/research/dime/brief/dime-gender-program 